Izr. prof. dr.

Lea Bregar

Ekonomska fakulteta Univerze $v$ Ljubljani

\title{
URESNIČEVANJE POTENCIALOV
} E-IZOBRAŽEVANIA V IZOBRAŽEVANJU ODRASLIH

\section{POVZETEK}

E-izobraževanje, katerega bistvena značilnost je uporaba sodobne informacijske in telekomunikacijske tehnologije (IKT), odpira nove perspektive in možnosti za pridobivanje in kreiranje znanja odraslega prebivalstva. Potencialne priložnosti e-izobraževanja so odvisne od tega, koliko in kako smotrno ter učinkovito je tehnologija integrirana v izobraževalni proces. Osnova za celovito uresničevanje potencialov, ki jih za izobraževanje odraslih omogoča sodobna tehnologija, je koncept celostnega e-izobraževanja. Za uresničitev teh potencialov morajo biti izpolnjeni določeni dejavniki, ki vplivajo na povpraševanje in ponudbo programov e-izobraževanja. Analiza stanja v EU in Sloveniji kaže, da je e-izobraževanje še vedno obrobna oblika izobraževanja odraslih. Glavni vzroki za skromno izkoriščenost potencialov e-izobraževanja pri izobraževanju so nezadostna usposobljenost velikega dela odraslega prebivalstva za uporabo sodobne tehnologije, neustrezna in skromna ponudba programov ter enostransko uresničevanje strategije uvajanja IKT v izobraževanje.

Ključne besede: e-izobraževanje, izobraževanje odraslih, vseživljenjsko učenje, digitalna pismenost.

bseg znanja se v sodobnih družbah pospešeno povečuje in hkrati izjemno hitro zastareva. Priče smo fenomenu razpolovitve življenjske dobe znanja (half-life knowledge). Polovica današnjega znanja pred desetimi leti sploh ni obstajala (Siemens, 2004). Mladina s svežim znanjem iz šolskih klopi predstavlja na trgu dela zanemarljiv delež, saj je med zaposlenimi komaj približno deset odstotkov takih, ki so končali formalno izobraževanje v obdobju zadnjih štirih let.

Potreba po stalnem in čim bolj celovitem obnavljanju in širjenju znanja je danes splošno spoznana in utemeljena s konceptom vseživljenjskega učenja. Pomen vseživljenjskega učenja v sodobnih družbah povečujejo še drugi, med seboj prepleteni dejavniki: spremenjena demografska struktura in staranje prebivalstva $\mathrm{v}$ razvitih državah in podaljševanje življenjske dobe, dvigovanje starostne meje upokojevanja, intenzivni integracijski in globalizacijski procesi ter nenehni tehnološki razvoj. Koncept vseživljenjskega učenja je danes eno standardnih izhodišč izobraževalnih politik in strategij na različnih institucionalnih ravneh pri nas in v svetu.

Vendar udejanjanje vseživljenjskega učenja ne dopušča preprostega prenosa tradicionalnih izobraževalnih modelov v izobraževanje odraslega prebivalstva. Vseživljenjsko učenje mora odgovarjati raznovrstnim in spremenljivim izobraževalnim potrebam, ki jih narekujejo trg dela, zahteve po konkurenčnosti delovne sile $\mathrm{v}$ 
sodobnih družbah, ob sočasni skrbi za zmanjševanje družbene izključenosti, ter značilnosti odraslih v izobraževanju nasploh. Učinkovito vseživljenjsko učenje potrebuje več fleksibilnosti pri tempu, prostoru, vsebinah in času študija. Odgovor na te zahteve je uvajanje novih oblik izobraževanja in učenja, ki jih označujejo pojmi, kot so odprto učenje, fleksibilno učenje, porazdeljeno učenje, aktivno in problemsko učenje in podobno.

E-izobraževanje, katerega bistvena značilnost je uporaba sodobne informacijske in telekomunikacijske tehnologije (IKT), odpira nove perspektive in možnosti za pridobivanje in kreiranje znanja odraslega prebivalstva. Potencialne priložnosti e-izobraževanja pa so odvisne od tega, koliko in kako smotrno ter učinkovito je tehnologija integrirana $\mathrm{v}$ izobraževalni proces. Prispevek je namenjen analizi potencialov e-izobraževanja pri izobraževanju odraslih in uresničevanju teh potencialov v našem prostoru, to je $v$ Evropski uniji in Sloveniji. Identifikacija potencialov e-izobraževanja je odvisna od razumevanja samega pojma e-izobraževanja. Ker je e-izobraževanje $v$ teoriji in praksi definirano precej ohlapno, začenjamo prispevek z razpravo o samem konceptu e-izobraževanja. Pri identifikaciji potencialov e-izobraževanja izhajamo iz ožje pojmovanega e-izobraževanja (celostnega e-izobraževanja). V nadaljevanju bomo opredelili pogoje za ponudbo in povpraševanje, od katerih je odvisna uresničljivost potencialov e-izobraževanja. Prispevek bomo zaključili z oceno izpolnjenosti pogojev za uresničevanje potencialov e-izobraževanja, ki nakazuje tudi vzroke za skromno prisotnost e-izobraževanja v izobraževanju odraslih v Sloveniji in EU.

\section{OPREDELITEV E-IZOBRAŽEVANJA}

Razprava o potencialih e-izobraževanja zahteva najprej jasno opredelitev samega pojma eizobraževanje. E-izobraževanje je v splošnem opredeljeno kot izobraževanje, pri katerem se uporablja IKT (Clarey, 2007).

Pregled strokovne literature in različnih gradiv, povezanih z opredelitvijo e-izobraževanja, razkriva precejšnjo neenotnost in ohlapnost pri razlagi tega pojma. Nejasni in slabo opredeljeni pogledi o samem konceptu e-izobraževanja povzročajo težave $\mathrm{v}$ strokovnih razpravah in pri samem vpeljevanju e-izobraževanja. Različni koncepti e-izobraževanja, ki jih udejanjajo programi e-iz-
Pojem e-izobraževanje razkriva nekonsistentnosti in nejasnosti. obraževanja, pa vplivajo tudi na prednosti in omejitve, ki jih lahko pričakujemo od izvedbe teh programov. $\mathrm{V}$ nadaljevanju se bomo zato ustavili pri opredelitvi pojma e-izobraževanje. To, kar pravzaprav razumemo z e-izobraževanjem, lahko razdelimo $v$ dve skupini: e-izobraževanje v širšem smislu in ožje opredeljeno e-izobraževanje.

\section{E-IZOBRAŽEVANJE V ŠIRŠEM SMISLU (DELNO TEHNOLOŠKO PODPRTO IZOBRAŽEVANJE)}

Prva skupina združuje poglede, ki obravnavajo e-izobraževanje kot vsako izobraževanje, pri katerem je prisotna tehnološka komponenta. $\mathrm{Na}$ širše pojmovano e-izobraževanje, torej uporabo IKT pri izobraževanju, naletimo običajno v tradicionalnem izobraževanju. V tradicionalnem izobraževanju nastopa IKT kot ena od sestavin učnega procesa, ki je namenjena le njegovi dopolnitvi ali obogatitvi, ne posega pa $\mathrm{v}$ konceptualne osnove in $\mathrm{v}$ osnovno doktrino tradicionalno zasnovanega učnega procesa. Eizobraževanje, pojmovano v širšem smislu, je, po našem mnenju, smiselno poimenovati delno tehnološko podprto izobraževanje. Primeri delno tehnološko podprtih izobraževalnih programov segajo od najbolj enostavnih uporab IKT, kot so na primer objave izobraževalnih programov, urnikov, predmetnikov ali učnih 
gradiv na zgoščenki ali na spletu, uporaba elektronske pošte in uporaba spletnih virov, do kompleksnejših in zahtevnejših oblik uporabe, kot so na primer spletne diskusije in spletni projekti. Temeljne značilnosti delno tehnološko podprtega izobraževanja so:

E-izobraževanje $v$ širšem smislu pomeni delno tehnološko podprto izobraževanje.
- IKT se uporablja parcialno in nepovezano pri posameznih elementih učnega procesa ali pri njegovi administrativni podpori;

- učni proces temelji na nespremenjenih pedagoških konceptih tradicionalnega izobraževanja;

- obseg dela v razredu (face-to-face teaching) je praktično nespremenjen. Potenciali, ki jih omogoča delno tehnološko podprto izobraževanje, so odvisni od tega, koliko in kako je tehnologija vključena $\mathrm{v}$ izobraževalni proces ter kako smotrno in učinkovito se izobraževalni proces prilagaja tehnologiji.

\section{OŽJE POJMOVANO E-IZOBRAŽEVANIE (CELOSTNO E-IZOBRAŽEVANJE)}

Druga skupina obravnava e-izobraževanje ožje, bolj določno. Bistvena razlika med delno tehnološko podprtim izobraževanjem in ožje pojmovanim e-izobraževanjem (poimenujmo ga celostno e-izobraževanje) je $\mathrm{v}$ tem, da pri celostnem e-izobraževanju tehnološka podpora ni prisotna le parcialno, pri posameznih elementih izobraževalnega procesa, ampak je celostno integrirana $v$ vse elemente izobraževalnega procesa. To pomeni, da je vključena $\mathrm{v}$ pedagoško podporo, $\mathrm{v}$ administrativno podporo ter $\mathrm{v}$ študijska gradiva in omogoča, da se učni proces izvaja ob fizični ločenosti učitelja in študenta. E-izobraževanje $\mathrm{v}$ ožjem smislu pomeni celostno tehnološko podprto izobraževanje.

Prostorska ločenost učitelja in udeleženca v izobraževalnem procesu omogoča večjo fleksibilnost izobraževanja, kar je bistvena značilnost

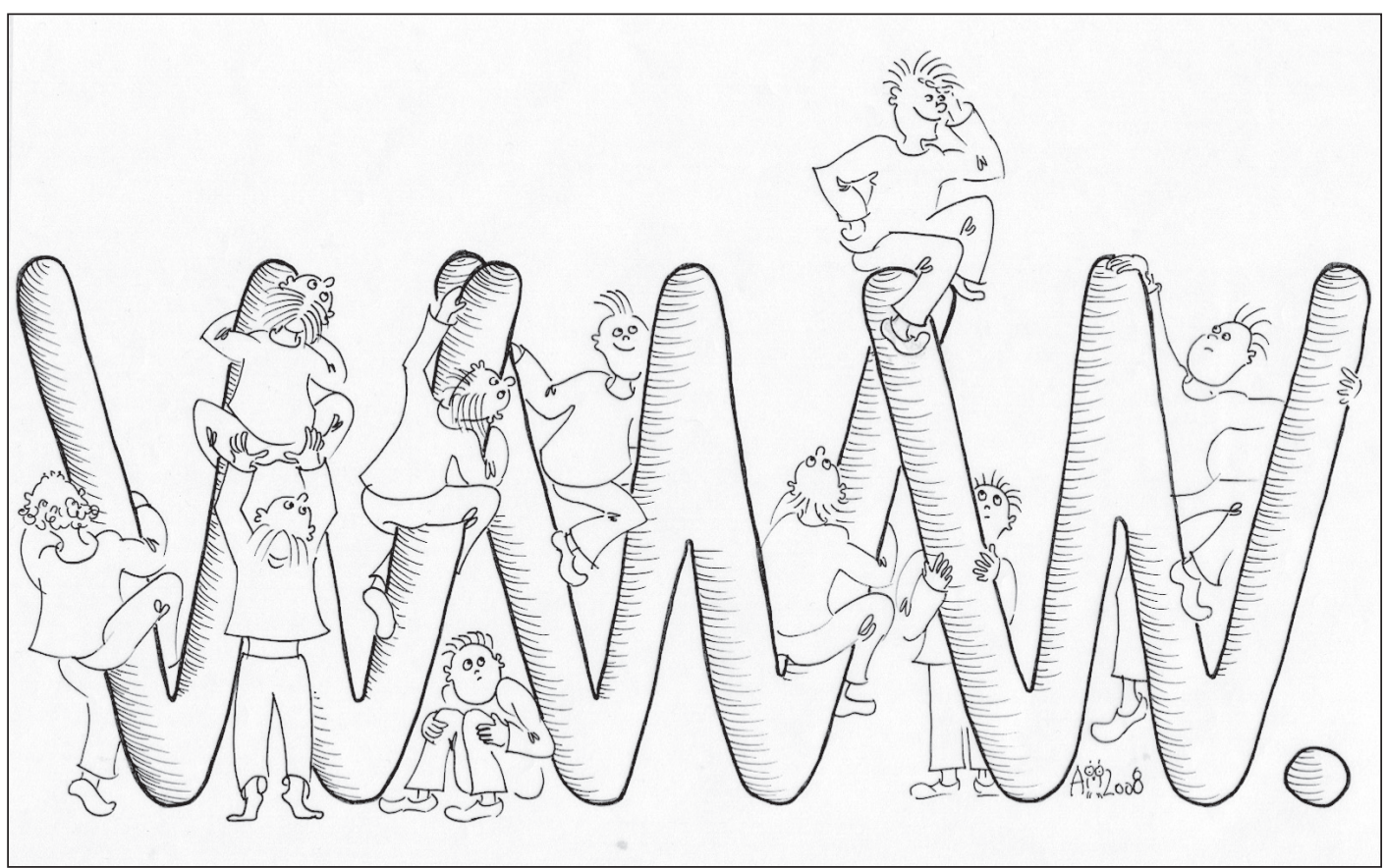


Celostno e-izobraževanje je torej sodobna, s pomočjo IKT izboljšana inačica študija na daljavo. Poleg prostorske neodvisnosti in tehnološko podprte komunikacije udeležencev v učnem procesu jo odlikuje še ena bistvena značilnost: dostopnost do novih virov znanja, kar omogoča uresničevanje sodobnih pedagoških modelov, usmerjenih k ustvarjanju novega znanja, v pedagoški praksi. ${ }^{2}$

tradicionalnega študija na daljavo (distance education). Zaradi prostorske fleksibilnosti so se $\mathrm{z}$ razmahom tradicionalnega študija na daljavo (ŠND) bistveno izboljšale izobraževalne možnosti pomembnega dela prebivalstva, med drugimi tudi odraslega prebivalstva.

Fizična ločenost pa je prinesla tudi določene pomanjkljivosti ŠND, povezane zlasti z odsotnostjo oziroma s slabšimi možnostmi interakcije in komunikacije v izobraževalnem procesu. Ravno te pomanjkljivosti pa je mogoče danes relativno uspešno obvladovati z uporabo sodobne IKT, in to z različnimi oblikami tehnološko podprte sinhrone in asinhrone komunikacije.
Vmesna stopnja med delno tehnološko podprtim izobraževanjem in celostnim e-izobraževanjem je tako imenovano (kombinirano) mešano izobraževanje (blended learning). Tako izobraževanje sicer ne izključuje neposrednih (tradicionalnih) oblik poučevanja, vendar se te pojavljajo kot dopolnilne $\mathrm{v}$ razmeroma omejenem obsegu.

\section{OBLIKE IZOBRAŽEVANJA, OBSEG IN INTEGRIRANOST TEHNOLOŠKE PODPORE V IZOBRAŽEVALNEM PROCESU}

Navedene oblike izobraževanja se torej razlikujejo po relativnem pomenu tehnološke podpore $\mathrm{v}$ izobraževalnem procesu in po tem, ali je učinkovita uporaba tehnološke komponente podprta s smotrnimi in učinkovitimi pedagoškimi, organizacijskimi, kadrovskimi in finančnimi rešitvami.

V tabeli 1 povzemamo glavne razlike $\mathrm{v}$ značilnostih delno tehnološko podprtega izobraževanja (DTPI) in celostnega e-izobraževanja (CEI).

Slika 1: Obseg in stopnja integriranosti tehnološke podpore pri različnih oblikah izobraževanja

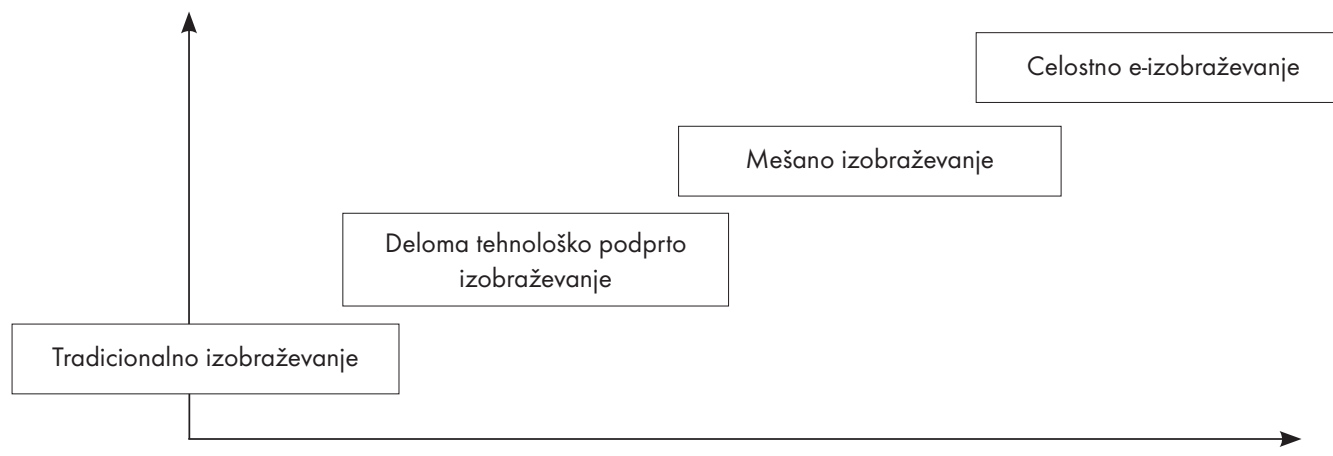

Tabela 1. Primerjava značilnosti delno tehnološko podprtega izobraževanja in celostnega e-izobraževanja.

\begin{tabular}{|l|l|l|}
\hline \multirow{2}{*}{ Značilnosti } & \multicolumn{2}{c|}{ Tehnološko podprto izobraževanje } \\
\cline { 2 - 3 } & \multicolumn{1}{|c|}{ DTPI } & \multicolumn{1}{c|}{ CEI } \\
\hline Uporaba IKT & Parcialna in nepovezana & Celostno integrirana v izobraževalni proces \\
\hline Komunikacija & Pretežno v razredu & Prostorsko neodvisna, podprta z IKT \\
\hline Pedagoški koncepti in modeli & Tradicionalni & $\begin{array}{l}\text { Sodobni, usmerieni k udeležencu in k ustvarjanju } \\
\text { novega znanja }\end{array}$ \\
\hline
\end{tabular}


Celostno e-izobraževanje označujejo (Paulsen, 2003):

- prostorska ločenost učitelja in udeleženca izobraževanja;

- aktivna vloga izobraževalne organizacije v izobraževalnem procesu;

- posredovanje izobraževalnih vsebin v elektronski obliki, praviloma po internetu;

- zagotovitev dvosmerne komunikacije prek elektronskega omrežja (udeleženci izobraževalnega procesa komunicirajo med seboj, z učitelji in drugim osebjem izobraževalne organizacije). Navedene značilnosti celostnega e-izobraževanja odpirajo naslednje strateške priložnosti v izobraževanju: možnost izvedbe učnega procesa ob fizični ločenosti udeleženca in učitelja, različne oblike tehnološko podprte komunikacije med učečimi, učitelji in preostalimi udeleženci; dostop do novih virov znanja.

\section{POTENCIALI E-IZOBRAŽEVANJA}

Izraba priložnosti celostnega e-izobraževanja lahko prispeva $\mathrm{k}$ večji kakovosti in učinkovitosti izobraževanja $\mathrm{v}$ izobraževalnih ustanovah in tudi širše, na nacionalni ravni in v mednarodnih okvirih. E-izobraževanje omogoča zmanjševanje določenih stroškovnih kategorij (stroški učnega osebja; stroški najemnin in drugi stroški, povezani s prostori), ponuja možnosti bolj kakovostnih storitev; povečuje preglednost in

Pri vpeljevanju e-izobraževanja moramo računati tudi $\mathrm{z}$ mnogimi problemi in omejitvami, povezanimi predvsem $\mathrm{z}$ visokimi začetnimi stroški razvoja programov, z zagotavljanjem tehnične in informacijske infrastrukture, s kompleksnimi problemi avtorstva in dostopnostjo programov, omejenostjo kadrovskih in drugih virov ter nasploh še vedno skromnim poznavanjem sodobnih, tehnološko podprtih oblik izobraževanja. dokumentiranost izvedbe programov in konsistentnost izvedbe; lahko prispeva k bolj objektivnemu ocenjevanju; izboljšuje dostopnost do kakovostnih virov; omogoča uvajanje sodobnih pedagoških modelov in inoviranje pedagoškega procesa; daje boljše možnosti trženja izobraževalnih programov in internacionalizacije. ${ }^{3}$

$\mathrm{V}$ tem prispevku se osredotočamo na analizo potencialnih prednosti e-izobraževanja $\mathrm{z}$ vidika odraslih udeležencev izobraževanja.

\section{POTENCIALI E-IZOBRAŽEVANIA V IZOBRAŽEVANJU ODRASLIH}

Kot najznačilnejše prednosti e-izobraževanja z vidika udeleženca izobraževanja se ponavadi navajajo:

- večja fleksibilnost v času, kraju, tempu in vsebini izobraževanja (just-in-time learning, just-in-place learning);

- večja interaktivnost in hitrejši dostop do znanja iz različnih virov (sinhrone in asinhrone oblike komunikacije, spletni viri);

- možnosti prilagajanja vsebin in učnih slogov potrebam posameznika;

- preglednost in transparentnost pogojev izobraževanja;

- razvoj novih znanj in kompetenc.

Poglejmo, s kakšnimi pristopi in učnimi strategijami je mogoče prilagajati proces učenja v pogojih e-izobraževanja značilnostim odraslih. Pri tem izhajamo iz značilnosti odraslih v izobraževanju, kot jih je opredelil utemeljitelj andragogike Malcolm Knowles (Knowles, 1985):

- odrasli se ponavadi odločajo sami;

- odrasli posedujejo mnogo življenjskih izkušenj, ki jim služijo kot vir učenja;

- ker pripravljenost odraslih za učenje pogosto izhaja iz konkretnih potreb, so bolj usmerjeni v življenjsko ali problemsko kot predmetno učenje;

- na splošno odrasle k učenju motivirajo notranji dejavniki (na primer pomoč otroku 
Ovrednotenje prednosti e-izobraževanja z vidika posebnih potreb, ki jih imajo v izobraževanju odrasli, kaže, da je e-izobraževanje pravzaprav oblika izobraževanja, pisana na kožo odraslim. Tony Bates, eden vodilnih teoretikov s področja e-izobraževanja, je zapisal, da je e-izobraževanje idealni način za vseživljensko učenje. Zagotavlja namreč potrebno dostopnost in fleksibilnost. Udeležencem z lastnimi izkušnjami pa omogoča, da svoje znanje delijo in poglabljajo v diskusijskih forumih (Bates, 2001: 26).

pri učenju), manj pa zunanji dejavniki (na primer ugled na delovnem mestu).

V spodnji tabeli prikazujemo nekatere tipične strategije in pristope celostnega e-izobraževanja, ki so posebno primerni za izobraževanje odraslih glede na njihove značilnosti.

\section{POGOII ZA URESNIČEVANJE PO- TENCIALOV E-IZOBRAŽEVANIA V IZOBRAŽEVANJU ODRASLIH}

Na začetni stopnji uporabe sodobne IKT v izobraževanju, ki sega nekako v drugo polovico devetdesetih let prejšnjega stoletja, so teoretiki in praktiki zaneseno napovedovali, da bo razvoj IKT prinesel revolucionarne spremembe na področju izobraževanja.

Potencialne prednosti, zaradi katerih je konec prejšnjega stoletja Peter Drucker, utemeljitelj sodobnega menedžmenta, napovedoval, da rezidenčne univerze ${ }^{4}$ ne bodo preživele, pa se v praksi ne uresničujejo v pričakovanem obsegu.
Uresničitev potencialov e-izobraževanja zahteva namreč izpolnjenost določenih pogojev tako na strani povpraševanja, to je $\mathrm{z}$ vidika udeležencev izobraževanja, kot na strani ponudbe, to je z vidika izobraževalnih ustanov, ki ponujajo izobraževalne storitve; možnosti za uresničitev potencialov e-izobraževanja pa so odvisne tudi od značilnosti širšega okolja, predvsem izobraževalnega sistema. Z vidika udeležencev e-izobraževanja je uresničljivost potencialov e-izobraževanja odvisna predvsem od:

- razvitosti tehnične infrastrukture;

- stopnje digitalne pismenosti;

- stopnje obvladovanja samostojnega učenja in motiviranosti.

Izobraževalne ustanove morajo v splošnem poskrbeti za kakovostno ponudbo izobraževalnih programov, ki bo prilagojena potrebam izobraževanja odraslih. Na razvoj e-izobraževanja in s tem posredno na zagotavljanje ugodnih pogojev za uresničevanje e-izobraževanja pa vplivajo tudi splošne družbene značilnosti, zlasti značilnosti izobraževalnega sistema v državi (na primer, splošna raven izobrazbe, razširjenost izobraževanja odraslih in splošna uveljavljenost koncepta vseživljenjskega učenja, izdatki za izobraževanje, še posebno za tehnološko podporo izobraževanju, in podobno).

Poglejmo najprej, kakšne so možnosti za uresničevanje potencialov e-izobraževanja v izobraževanju odraslih z vidika udeležencev.

Tabela 2: Prilagajanje učnega procesa značilnostim odraslih v e-izobraževanju

\begin{tabular}{|l|l|}
\hline Značilnosti odraslih & Strategije in pristopi CEl \\
\hline Samostojnost pri odločanju & Fleksibilnost v izbiri učnih slogov in v izvedbi programa \\
\hline $\begin{array}{l}\text { Usmerjenost v problemsko usmerjeno } \\
\text { izobraževanje in v poglabljanje znanja }\end{array}$ & $\begin{array}{l}\text { Fleksibilnost izbire izobraževalnih vsebin, hiter in enostaven dostop do } \\
\text { novih virov, razvoj novih znanj in kompetenc }\end{array}$ \\
\hline Bogastvo življenjskih izkušenj & $\begin{array}{l}\text { Aktivna vloga pri ustvarjanju novega znanja s pomočjo tehnološko } \\
\text { podprte komunikacije }\end{array}$ \\
\hline Izobraževanje kot ena od aktivnosti & \begin{tabular}{l} 
Fleksibilnost izvedbe programa (z vidika časa, prostora in tempa izvajanja) \\
\hline
\end{tabular} \\
\hline
\end{tabular}

Uresničitev potencialov e-izobraževanja zahteva izpolnjenost pogojev ponudbe (izobraževalnih storitev in tehnološke infrastrukture) in povpraševanja (udeležencev). 
MOŽNOSTI URESNIČEVANJA POTENCIALOV E-IZOBRAŽEVANIA V IZOBRAŽEVANJU ODRASLIH Z VIDIKA UDELEŽENCEV

Osnovni pogoj za uvedbo celostnega e-izobraževanja, to je razpoložljiva tehnološka infrastruktura, ki je bil sprva glavna ovira, postaja danes manj pomemben omejitveni dejavnik.

Po podatkih Eurostata ${ }^{5}$ sta imeli leta 2007 v 25 državah članicah EU v povprečju dve tretjini gospodinjstev dostop do računalnika. $\mathrm{Na}$ enaki ravni je bila dostopnost do računalnika v Sloveniji. V EU-25 je imelo dostop do interneta 58 odstotkov gospodinjstev, v Sloveniji pa dobra polovica gospodinjstev (54 odstotkov). Pri tem ne smemo spregledati, da je tehnična kakovost povezav tako v EU-25 kot v Sloveniji še vedno precej skromna, saj je imela širokopasovni dostop do interneta manj kot polovica gospodinjstev. Dobra četrtina prebivalstva $\mathrm{v}$ starosti od 15 do 74 let v EU-25 (28 odstotkov) in skoraj tretjina prebivalstva (31 odstotkov) v Sloveniji po podatkih za leto 2007 še nikoli ni uporabila računalnika.

\section{ZA UČINKOVITO IZRABO POTEN- CIALOV E-IZOBRAŽEVANJA JE POTREBNA DOLOČENA STOPNIA DIGITALNE PISMENOSTI ${ }^{6}$}

Eurostat ocenjuje digitalno pismenost $\mathrm{z}$ dveh vidikov, kot računalniško in kot internetno pismenost, na osnovi samoocenjevanja, koliko od šestih naštetih računalniških oziroma internetnih nalog je posameznik po lastnem mnenju sposoben izpeljati. ${ }^{7} \mathrm{~V}$ tabelah 4 in 5 sta prikazani računalniška in internetna pismenost na treh stopnjah (na osnovni, srednji in visoki stopnji) za tri starostne skupine prebivalstva. Pregled rezultatov v tabeli 4 opozarja na velike razlike $\mathrm{v}$ računalniški pismenosti med starostnimi skupinami. Večina mlajših prebivalcev v starosti od 15 do 24 let je računalniško pismena (več kot 90 odstotkov), znaten del prebivalstva te starostne skupine dosega visoko stopnjo računalniške pismenosti, v EU-25 43 odstotkov in v Sloveniji skoraj dve tretjini (64 odstotkov).

Položaj je manj ugoden za osrednjo starostno skupino odraslega prebivalstva (od 25 do 54

Tabela 3: Tehnična infrastrukłura e-izobraževanja v državah EU-25 in v Sloveniji, v lełu 2007

\begin{tabular}{|l|c|c|}
\hline \multirow{2}{*}{ Kazalniki } & \multicolumn{2}{|c|}{$\mathrm{v} \%$} \\
\cline { 2 - 3 } & EU-25 & Slovenija \\
\hline Dostop gospodinjstev do računalnika & 66 & 66 \\
\hline Posamezniki, ki so uporabili računalnik v zadnjih treh mesecih & 65 & 58 \\
\hline Posamezniki, ki nikoli niso uporabili računalnika & 28 & 31 \\
\hline Dostop gospodinjstev do interneta & 58 & 54 \\
\hline Širokopasovni dostop do interneta v gospodinjstvih & 43 & 44 \\
\hline Redni uporabniki interneta & 53 & 49 \\
\hline
\end{tabular}

Vir: Eurostat, New Cronos, Infomation Society Statistics, Data; Policy indicators.

Tabela 4: Računalniška pismenost v državah EU-25 in v Sloveniji, v letu 2007

\begin{tabular}{|l|c|c|c|c|c|c|c|c|}
\hline \multirow{2}{*}{ Starostne skupine } & \multicolumn{9}{|c|}{$\vee \%$} \\
& \multicolumn{2}{|l|}{$\begin{array}{l}\text { Nizka računalniška } \\
\text { pismenost }\end{array}$} & \multicolumn{2}{l|}{$\begin{array}{l}\text { Srednja računalniška } \\
\text { pismenost }\end{array}$} & \multicolumn{2}{l|}{$\begin{array}{l}\text { Visoka računalniška } \\
\text { pismenost }\end{array}$} & \multicolumn{2}{l|}{ Skupaj } \\
\hline & EU-25 & SI & EU-25 & SI & EU-25 & SI & EU-25 & SI \\
\hline $16-24$ let & 12 & 6 & 36 & 26 & 43 & 64 & 91 & 96 \\
\hline $25-54$ let & 14 & 14 & 28 & 26 & 30 & 27 & 72 & 67 \\
\hline $55-74$ let & 11 & 8 & 14 & 8 & 8 & 6 & 33 & 22 \\
\hline
\end{tabular}

Vir: Eurostat, New Cronos, Infomation Society, Data; 
let), saj je delež računalniško pismenih (ne glede na stopnjo) v EU-25 (72 odstotkov), še bolj pa v Sloveniji, precej nižji (67 odstotkov). Dobra polovica tega starostnega kontigenta v EU-25 (58 odstotkov) in v Sloveniji (53 odstotkov) dosega srednjo ali visoko stopnjo računalniške pismenosti, slaba polovica pa je računalniško nepismena oziroma obvladuje le osnovne računalniške naloge.

Izrazito slab pa je položaj v skupini starejšega prebivalstva, saj se s srednjo ali visoko stopnjo računalniške pismenosti v EU-25 ponaša le dobra petina (22 odstotkov) prebivalstva te skupine, v Sloveniji pa komajda 14 odstotkov. Stanje o razlikah v internetni pismenosti med starostnimi skupinami je precej podobno kot pri računalniški pismenosti, le da je stopnja internetne pismenosti $\mathrm{v}$ glavnem nižja kot stopnja računalniške pismenosti. Tako dosega srednjo ali visoko internetno pismenost približno tretjina prebivalcev v starostni skupini od 25 do 54 let (34 odstotkov v EU-25 in 36 odstotkov v Sloveniji). Še bolj skrb zbujajoči so rezultati v skupini starejšega prebivalstva od 55 do 74 let, kjer dosega srednjo ali visoko stopnjo komaj devet odstotkov prebivalstva in v Sloveniji le šest odstotkov.

Navedeni podatki nesporno opozarjajo, da dostopnost e-izobraževanja bolj kot omejena tehnološka infrastruktura ogroža neusposobljenost odraslega prebivalstva za uporabo sodobne tehnologije. Četudi večina programov e-izobraževanja ne zahteva ravno najvišje stopnje digitalne pismenosti in se je osnovnih spretnosti, ki jih zahteva uporaba e-programov, mogoče precej hitro naučiti, pa nepoznavanje računalnika in interneta pri odraslem prebivalstvu vzbuja napačne predstave o zahtevnosti tehnološko podprtega učenja, pomisleke o njegovi ustreznosti za lastno izobraževanje in dvome o lastnih zmožnostih. Precej nizka stopnja digitalne pismenosti večine odraslega prebivalstva se torej kaže kot resen demotivacijski dejavnik vključevanja odraslega prebivalstva v e-izobraževanje.

\section{MOŽNOSTI URESNIČEVANIA POTENCIALOV E-IZOBRAŽEVA- NJA Z VIDIKA PONUDBE}

Pomemben motivacijski dejavnik za vključevanje odraslih je ustreznost ponudbe. Osnovni motiv odraslih za izobraževanje je zapolniti vrzel med tem, kar že znajo, in tem, kar si želijo ali morajo znati. Zanimanje odraslih za e-izobraževanje bo odvisno tudi od tega, ali je razpoložljiva ponudba $\mathrm{v}$ skladu $\mathrm{z}$ njihovimi potrebami.

Razvoj e-izobraževanja podrobneje opredeljuje poseben Nizka digitalna usposobljenost odraslega prebivalstva ogroža uresničitev potencialov e-izobraževanja. temeljni dokument, tako imenovana pobuda za e-izobraževanje (e-Learning Initiative, 2000), na kateri temeljita Akcijski načrt za e-izobraževanje za obdobje od 2001 do 2004 (e-Learning Action Plan) in Program za e-izobraževanje za obdobje od 2004 do 2006 (e-Learning Programme).

Od leta 2007 je IKT v izobraževanju obravnavan kot eden od štirih presečnih, povezovalnih

Tabela 5: Internetna pismenost v državah EU-25 in v Sloveniji, v letu 2007

\begin{tabular}{|l|l|l|l|l|l|l|l|l|}
\hline \multirow{2}{*}{ Starostne skupine } & \multicolumn{9}{|c|}{$\vee \%$} \\
\cline { 2 - 9 } & Nizka internetna pismenost & Srednja internetna pismenost & Visoka internetna pismenost & Skupaj \\
\hline & EU-25 & SI & EU-25 & SI & EU-25 & SI & EU-25 & SI \\
\hline $16-24$ let & 22 & 20 & 45 & 45 & 24 & 28 & 81 & 93 \\
\hline $25-54$ let & 36 & 33 & 26 & 26 & 8 & 10 & 70 & 69 \\
\hline $55-74$ let & 22 & 12 & 8 & 5 & 1 & 1 & 31 & 18 \\
\hline
\end{tabular}

Vir: Eurostat, New Cronos, Infomation Society, Data; 
$\mathrm{Na}$ ponudbo e-izobraževalnih storitev vplivajo tudi širše družbene značilnosti, posebno pa značilnosti izobraževalnega sistema v državi. Širše okolje v EU in v Sloveniji je razvoju e-izobraževanja precej naklonjeno, saj je ima e-izobraževanje oziroma tehnološko podprto izobraževanje in usposabljanje vidno mesto $\mathrm{v}$ razvojnih dokumentih EU. Evropska komisija je tako v lizbonski strategiji jasno izpostavila potencial IKT za doseganje osnovnega strateškega cilja EU, to je postati najbolj konkurenčna, na znanju temelječa družba.

sestavin programa vseživljenjskega učenja in kot prednostna usmeritev v programih Erasmus, Comenius, Leonardo da Vinci in Grundtvig (Use of ICT to support innovation and lifelong learning for all, 2008: 4).

Podobne poglede o razvojni vlogi izobraževanja in IKT imamo na deklarativni ravni tudi v Sloveniji. Slovenija obravnava, podobno kot druge evropske države, ustvarjanje, pretok in uporabo znanja kot enega bistvenih pogojev za doseganje temeljnih družbenih razvojnih ciljev. Pri tem navaja kot eno Povpraševanje po e-izobraževanju je skromno. od prioritet spodbujanje vseživljenjskega učenja (Strategija razvoja Slovenije: 9) in poudarja potrebo »povečati dostop do izobraževanja in usposabljanja s pomočjo novih tehnologij, in sicer z ustanavljanjem z IKT podprtih regionalnih in lokalnih točk vseživljenjskega učenja« (Strategija razvoja Slovenije: 29). ževanje v EU in Sloveniji uresničevala prek številnih finančno zajetnih projektov, pa so rezultati na področju e-izobraževanja odraslih precej enostranski, nespodbudni in skromni. Zadnje desetletje je namreč prispevalo predvsem k izboljšanju tehnološke infrastrukture, medtem ko je učinkovitost izrabe IKT v izobraževanju še vedno na nizki ravni. Poročilo evropske komisije o napredku pri uporabi IKT
Četudi se je strategija uvajanja IKT v izobra- za razvoj vseživljenjskega učenja opozarja, da inoviranje poslovnih in javnih storitev s pomočjo IKT še ni doseglo procesov poučevanja in učenja. Potencial IKT, da omogoči učenje kot neprekinjen proces, ki bi z vseživljenjskim učenjem zajemal formalno in neformalno učenje ter učenje ob delu, pa še ni uresničen (Use of ICT to support innovation and lifelong learning for all, 2008: 4).

E-izobraževanje se v EU in Sloveniji sicer uveljavlja in širi, vendar gre še vedno v veliki meri za parcialno in nepovezano uporabo IKT v učnem procesu. Prevladujoči način posredovanja znanja še vedno poteka $\mathrm{v}$ predavalnicah, seveda ob podpori IKT, na ravni deloma tehnološko podrtega izobraževanja, ne pa celostnega e-izobraževanja.

Še vedno velja prepričanje, da je e-izobraževanje mogoče uvesti s preprostim prenosom obstoječih izobraževalnih gradiv na svetovni splet. Pozablja pa se, da je potenciale e-izobraževanja mogoče uresničiti le s celostnim e-izobraževanjem, ki zahteva tudi prilagoditev pedagoških konceptov, ki jih mora z ustrezno organizacijsko, finančno in kadrovsko shemo podpirati izobraževalna ustanova (Bregar, 2002). Na strani izobraževalnih ustanov lahko glavne vzroke za precej številne neuspele poskuse uvajanja e-izobraževanja iščemo v neustreznih kadrih, neprimernem menedžmentu ter v površnem in nezadostnem poznavanju e-izobraževanja.

Na drugi strani lahko identificiramo vzroke za neuspele poskuse uvajanja e-izobraževanja $\mathrm{v}$ neprimerno kvalificiranemu kadru, neprimernemu menedžmentu in nezadostnem poznavanju zakonitosti e-izobraževanja.

Študija »Megatrends in e-learning: e-learning initiatives that did not reach the targeted goals «, ki je raziskovala vzroke desetih neuspešnih projektov e-izobraževanja v ZDA, Veliki Britaniji, na Norveškem in Madžarskem, je na primer pokazala, da so bile glavne šibke točke:

- neustrezne priprave za uvajanje programov e-izobraževanja (pomanjkljive raziskave trga in nerealne ocene potencialnega trga); 


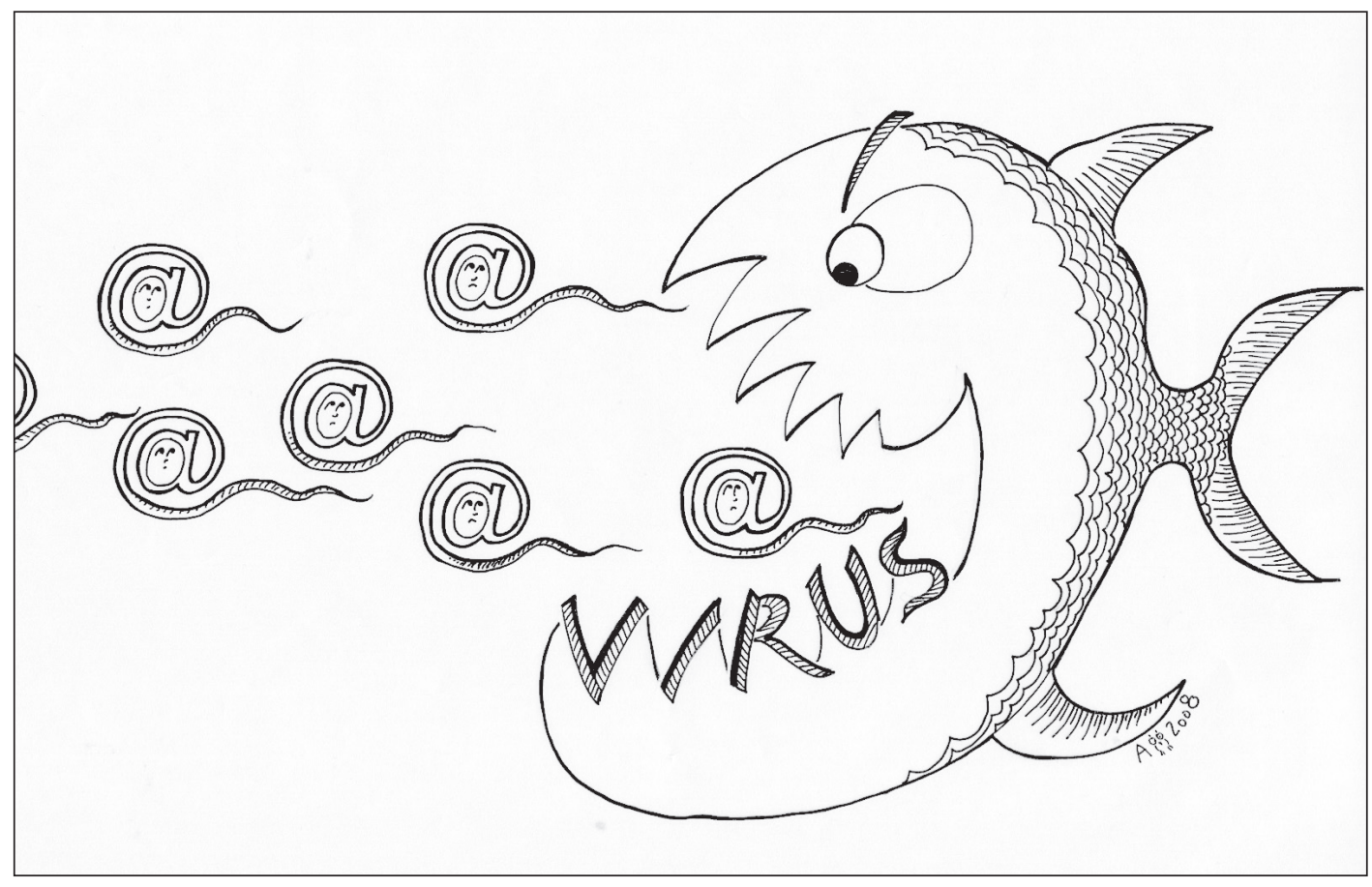

- pomanjkljivo načrtovanje stroškov in prihodkov, ne da bi upoštevali posebnosti ekonomike e-izobraževanja;

- neustrezna izbira in akreditacija e-programov;

- slaba presoja možnosti vstopa v dejavnost e-izobraževanja in neupoštevanje moči konkurentov;

- neustrezni menedžment, ki pri načrtovanju ni enakovredno upošteval obeh temeljnih komponent programov e-izobraževanja, to sta priprava zasnove in izvedbenega modela ter poslovnega načrta.

Tudi Slovenija je priložnosti, ki jih ponuja e-izobraževanje nasploh in tudi v vseživljenjskem učenju, do zdaj izkoristila precej skromno, saj razen nekaterih posamičnih poskusov s to obliko izobraževanja nimamo posebno spodbudnih izkušenj. V Sloveniji interes za sodobne oblike izobraževanja in usposabljanja sicer narašča na različnih ravneh izobraževanja, vendar gre predvsem za obogatitev tradicionalnega izobraževanja (Arh, 2006). Za zdaj je na voljo za izobra- ževanje oziroma usposabljanje le razmeroma skromen obseg programov e-izobraževanja v slovenskem jeziku.

Rezultati raziskave o razširjenosti študija na daljavo na področju izobraževanja odraslih opozarjajo, da ponujajo izvajalci programov izobraževanja in učenja odraslih le malo programov e-izobraževanja. Od 323 ponudnikov izobraževalnih programov jih je $\mathrm{v}$ študijskem letu 2005/2006 ponujalo programe e-izobraževanja le 22 oziroma 6,8 odstotka. (Zagmajster, 2006: 5).

Neustrezno in nezadostno ponudbo z vidika celostnega e-izobraževanja v EU in Sloveniji potrjujejo tudi rezultati ankete o uporabi interneta za izobraževanje pri rednih uporabnikih interneta ${ }^{8}$ za leto 2007. Podatek o uporabi interneta za opravljanje tečajev po internetu lahko uporabimo kot grob približek kazalnika o razpoložljivosti programov celostnega e-izobraževanja v EU-25-in Sloveniji, ${ }^{9}$ saj neposrednih podatkov o ponudbi programov e-izobraževanja $\mathrm{v}$ EU in Sloveniji ni na voljo. 
Tabela 6: Uporaba interneta za izobraževanje pri rednih uporabnikih interneta v državah EU-25 in v Sloveniji v letu 2007

\begin{tabular}{|c|c|c|c|c|c|c|}
\hline \multirow{4}{*}{ Starostne skupine } & \multicolumn{6}{|c|}{$v \%$} \\
\hline & \multicolumn{6}{|c|}{ Uporaba interneta $v$ izobraževanju za: } \\
\hline & \multicolumn{2}{|c|}{$\begin{array}{l}\text { pridobivanje informacij o } \\
\text { izobraževalnih možnostih }\end{array}$} & \multicolumn{2}{|c|}{$\begin{array}{l}\text { opravljanje tečajev po } \\
\text { internetu }\end{array}$} & \multicolumn{2}{|c|}{$\begin{array}{l}\text { pridobivanje novih znani, } \\
\text { informacij }\end{array}$} \\
\hline & EU-25 & Slovenija & EU-25 & Slovenija & EU-25 & Slovenija \\
\hline 16-24 let & 42,9 & 37,1 & 5,0 & 3,1 & 47,3 & 48,5 \\
\hline $25-54$ let & 21,2 & 19,7 & 3,3 & 2,5 & 26,1 & 26,4 \\
\hline $55-74$ let & 4,6 & 2,2 & 0,1 & 0,2 & 8,7 & 4,4 \\
\hline
\end{tabular}

Vir: Eurostat, New Cronos, Infomation Society, Data;

Ugotavljamo, da je delež rednih uporabnikov interneta $\mathrm{v}$ skupnem številu prebivalcev, ki so $\mathrm{v}$ zadnjih treh mesecih opravljali kakršen koli tečaj po internetu, izjemno nizek, in to za vse starostne skupine; ta delež je najvišji (5 odstotkov) v EU-25 v starostni skupini od 16 do 24 let. V Sloveniji je ta delež za primerljivo starostno skupino precej nižji (komaj tri odstotke), še malo nižji (2,5 odstotka) pa je v starostni skupini od 25 do 54 let. Starejše prebivalstvo (od 55 do 74 let) pa se $\mathrm{z}$ opravljanjem tečajev po internetu praktično ne ukvarja. Navedeni podatki potrjujejo, da je e-izobraževanje ( $v$ smislu celostnega izobraževanja) tako v EU kot v Sloveniji še vedno obrobna oblika izobraževanja, in to

E-izobraževanje je danes še vedno obrobna oblika izobraževanja za vse starostne skupine. za vse starostne skupine. V takšnih okoliščinah ostajajo priložnosti, ki jih omogoča IKT v izobraževanju, v veliki meri neizkoriščene.

Malo bolj spodbudni rezultati se kažejo pri uporabi interneta za posamezne aktivnosti izobraževalnega procesa, kar bi lahko označili kot tehnološko deloma podprto izobraževanje. Skoraj polovica prebivalstva $\mathrm{v}$ starosti od 16 do 24 let v EU-25 in Sloveniji uporablja internet kot informacijski vir pri učenju (consulting the internet with the purpose of learning), malo manjši delež te starostne skupine pa uporablja internet za pridobivanje informacij o izobraževalnih priložnostih (information about education, training or course offers). Podobno kot na področju računalniške in internetne pismenosti pa starejše prebivalstvo tako v EU-25 kot v Sloveniji uporablja internet kot informacijski vir $\mathrm{v}$ procesu učenja in kot vir za možnosti učenja bistveno manj kot mladina. Potenciali IKT se torej omejeno uresničujejo na področju delno tehnološko podprtega izobraževanja, in to pretežno v skupini mladih.

\section{ZAKLJUČEK}

E-izobraževanje razumemo kot generični pojem za izobraževanje, pri katerem se uporablja IKT. Potenciali, ki jih e-izobraževanje omogoča, so odvisni od obsega in stopnje integriranosti tehnološke podpore v izobraževalni proces. Celostno e-izobraževanje, ki temelji na prostorski neodvisnosti udeležencev $\mathrm{v}$ procesu izobraževanja, tehnološko podprti komunikaciji in odprtosti do novih virov znanja, je osnova za celovito uresničevanje potencialov, ki jih omogoča učinkovita in smotrna uporaba IKT v izobraževanju. Nove izobraževalne priložnosti, ki jih ponuja celostno e-izobraževanje, še posebno odgovarjajo izobraževalnim potrebam odraslih.

Za uresničevanje teh potencialov morajo biti izpolnjeni določeni pogoji, tako na strani povpraševanja, z vidika udeležencev, kot tudi na strani ponudbe.

Pregled stanja v EU-25 in Sloveniji odkriva, da je e-izobraževanje pri odraslih zelo skromno. Vzroke za tako stanje lahko iščemo v neusposobljenosti odraslega prebivalstva za izobraževanje $\mathrm{s}$ pomočjo IKT in $\mathrm{v}$ skromni 
ponudbi ustreznih programov. Takšno stanje je posledica površinskega razumevanja e-izobraževanja in tudi enostranskega uresničevanja strategije uvajanja IKT v izobraževanje. Četudi je izobraževanje s pomočjo tehnologije ena od strateških usmeritev EU, katere uresničevanje že dobro desetletje spremlja poraba precejšnjih finančnih sredstev, pa se rezultati teh usmeritev kažejo predvsem na področju formalnega izobraževanja s precejšnjimi investicijami $\mathrm{v}$ infrastrukturo in $\mathrm{v}$ usposabljanje mladine, bistveno manj pa na področju izobraževanja odraslih.

Takšna gibanja poglabljajo generacijsko vrzel $\mathrm{v}$ digitalni pismenosti, zlasti z vidika dosežene ravni digitalne pismenosti. To pa odpira resna vprašanja o enakih možnosti pridobivanja znanja in vključevanja na trgu dela med generacijami, še posebno če upoštevamo posledice staranja prebivalstva in nujnosti podaljševanja delovne dobe za aktivno prebivalstvo. Vzpostavljanje pogojev, ki omogočajo uresničevanje potencialov e-izobraževanja v izobraževanju odraslih, vidimo na današnji stopnji uvajanja IKT v izobraževanje kot nujno strateško prioriteto.

\section{LITERATURA IN VIRI}

Arh, Tanja (2007). »Struktura ponudbe e-izobraževanja v Sloveniji. Raba interneta v Sloveniji«. (http:// www.ris.org/index.php?fl=2\&lact=1\&bid=1518\&avt or $=80 \&$ parent $=17,17.12 .2007)$.

Bates, Tony (2001). National strategies for e-learning in post-secondary education and training. Fundamentals of educational planning. No. 70. Paris: UNESCO, str. 135. (http://unesdoc.unesco.org/ images/0012/001262/126230e.pdf, 5. 6. 2008.)

Bregar, Lea. (2002). »Razvojne možnosti e-izobraževanja v svetu in Sloveniji: e-izobraževanje kot sestavni del izobraževalne ponudbe«. Andragoška spoznanja, Ljubljana, 8, 3/4, str. 36-41.

Bregar, Lea, Radovan, Marko, Zagmajster, Margerita, Novak, Darijan (2007). Spletni program o e-izobraževanju: elektronski učbenik. Ljubljana: Andragoški center Slovenije (http://www.naberi.si/znanje/eUcenje, 15. 1. 2008).
Clarey, Janet (2007). E-learning 101: »An introduction to e-learning, learning tools and technologies«. Brandon Hall, 57 str.

Demunter, Christophe (2006). »How skilled are Europeans in using computers and Internet «. Statistics in Focus, 17/2006. Luxembourg: Eurostat. str. 7.

E-Learning - Designing tomorrow's education (2000). »Communication from the Commission«. Brussels: Commission of the European Communities, str. 13.(http://europa.eu/eur-lex/en/com/cnc/2000/ com2000_0318en01.pdf, 15. 11. 2007).

Knowles, Malcolm (1985). Andragogy in Action: Applying Modern Principles of Adult Education. San Francisco: Jossey-Bass, str. 444.

Methodological manual for information society statistics. Survey year 2007, v 2.1 (2007). Luxembourg: Eurostat, str. 188.

New Cronos, Information Society, Data (2008). Statistics on HH/Indiv 2007 (EXCEL) v 03.12.2008. Luxembourg: Eurostat http://epp.eurostat.ec.europa. eu/portal/page?_pageid=2973,64549069,2973_6455 4066\&_dad=portal\&_schema=PORTAL, 1.12.2008). Paulsen Morten Flate (2003). Online education terms. NIKI Forlaget, str. 25. (http://www.studymentor.com/ studymentor/Terms.pdf, 30. 11. 2008).

SIBIS. Statistical indicators benchmarking the information society (2003). Brussels: European Commission, str. 241. (http://www.sibis-eu.org/handbook/ handbook.htm, 2.12.2008).

Siemens, George (2004). Categories of eLearning. October 18, 2004. ELearnspace. (http://www.elearnspace.org/Articles/16. 6. 2006).

Strategija razvoja Slovenije (2005). Ljubljana: UMAR. str. 54. (http://www.umar.gov.si/fileadmin/user_upload/projekti/02_StrategijarazvojaSlovenije.pdf, 10. 11. 2007)

Use of ICT to support innovation and lifelong learning for all. A report on progress (2008). Brussels: Commission of the European Communities. str. 45. (http://www.europarl.europa.eu/registre/docs_autres_ institutions/commission_europeenne/sec/2008/2629/ COM_SEC(2008)2629_EN.pdf, 1. 12. 2008).

Zagmajster, Margerita (2006): Pregled študija na daljavo na področju izobraževanja odraslih. Ljubljana: Andragoški center. str. 16. (http://www.ris.org/uploadi/editor/1157473788pp.pdf, 16.12.2007).

${ }^{1} \check{C}$ e na primer na internetu objavimo zapiske predavanj, namesto da jih objavimo v tiskani publikaciji, bo to zmanjšalo stroške gradiv in povečalo njihovo dostopnost. Sama objava na internetu pa še ne prinaša bolj aktivnega in samostojnega učenja. Priprava e-gradiv 
terja temeljito vsebinsko in oblikovno pripravo, ki mora izhajati iz ustreznih pedagoško-didaktičnih teorij ter upoštevati načela priprave gradiv za samostojni študij in posebnosti oblikovanja spletnih gradiv. Podrobneje smo problematiko priprave e-gradiv in razvoja programov e-izobraževanja predstavili v elektronskem učbeniku Spletni program o e-izobraževanju (http://www. naberi.si/znanje/eUcenje/).

2 Na podobnem razumevanju e-izobraževanja temelji strategija razvoja e-izobraževanja v EU, kot je zapisana v iniciativi za e-izobraževanje. »E-izobraževanje je pristop, ki je osredotočen na udeleženca izobraževanja in z uporabo nove multimedijske tehnologije ter interneta omogoča večjo kakovost učenja in sodelovanja v pogojih prostorske ločenosti ter izboljšuje dostop do virov in izobraževalnih storitev « (Use of ICT to support innovation and lifelong learning for all, 2008: 4).

${ }^{3}$ Navedene potencialne priložnosti so uresničljive tudi $v$ okviru delno tehnološko podprtega izobraževanja, vendar parcialno in nesistematično, odvisno od tega, kako je tehnološka komponenta vključena v izobraževalni proces.

${ }^{4}$ Za rezidenčne univerze je značilno, da izvajajo pedagoški proces $v$ glavnem na tradicionalni način, v predavalnicah.

${ }^{5}$ Osnovni vir podatkov $v$ tabelah 3 do 6 so rezultati ankete o uporabi IKT v gospodinjstvih, ki jo po usklajeni statistični metodologiji izvajajo nacionalni statistični uradi članic EU. Podatki se nanašajo na leto 2007. Rezultati ankete za leto 2008 so sicer že bili objavljeni novembra 2008, vendar smo zaradi analitično bogatejših možnosti izbrali za prikaz podatkov leto 2007. Leta 2007 je anketa namreč vključevala dodaten sklop vprašanj o uporabi interneta $v$ izobraževanju.

${ }^{6}$ Po metodologiji SIBIS označujejo digitalno pismenost naslednje spretnosti: komuniciranje po internetu, pri- dobivanje in nameščanje programskih orodij na računalnik, iskanje želenih informacij, preverjanje virov informacij, najdenih na internetu (SIBIS: 205).

${ }^{7}$ Računalniške naloge so: uporaba miške za izbiro določene funkcije ali programa; kopiranje ali premik dokumenta ali mape, uporaba »copy-paste" orodij za urejanje besedila na ekranu; uporaba osnovnih aritmetičnih obrazcev v preglednicah; tiskanje dokumentov; izdelava računalniških programov z uporabo posebnih jezikov za programiranje. Internetne naloge so: iskanje informacij s pomočjo iskalnikov, pošiljanje elektronskih sporočil s pripetimi dokumenti; objavljanje sporočil v klepetalnicah, $v$ novičarskih skupinah in spletnih diskusijskih forumih; telefoniranje s pomočjo interneta; souporaba datotek za izmenjavo filmov, glasbe in podobno po načelu P2P (peer-to-peer), oblikovanje spletnih strani. Kot osebe z nizko stopnjo računalniške oziroma internetne pismenosti so po veljavni metodologiji Eurostata obravnavane osebe, ki menijo, da so sposobne opraviti eno ali dve od naštetih nalog, s srednjo stopnjo pismenosti tri ali štiri naloge in z visoko stopnjo pismenosti pet ali šest nalog (Demunter, 2006: 7).

${ }^{8}$ Kot redni uporabniki so upoštevani tisti, ki so internet uporabili $v$ zadnjih treh mesecih vsaj enkrat.

${ }^{9}$ Po anketni metodologiji obsega opravljanje tečajev po internetu (doing on-line course of any subject) vse učne programe oziroma tečaje, ki so prostorsko ločeni od izobraževalne ustanove ali podjetja. Interakcija z učitelji in drugim učnim osebjem ali študijskim gradivom poteka po internetu. Uporaba programskih orodij lahko ima opazno vlogo v programu. (Methodological manual for information society statistics, 2007: 115). Takšna opredelitev se v grobem ujema $z$ definicijo celostnega izobraževanja z opozorilom, da posebej ne izpostavlja dostopnosti informacijskih virov. 